Review

\title{
Listeria monocytogenes dissemination in farming and primary production: Sources, shedding and control measures
}

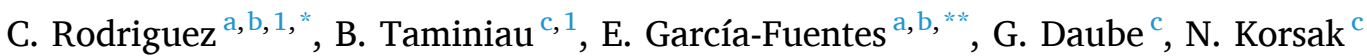 \\ ${ }^{a}$ Instituto de Investigación Biomédica de Málaga-IBIMA, Málaga, Spain \\ ${ }^{\mathrm{b}}$ Unidad de Gestión Clínica de Aparato Digestivo, Hospital Universitario Virgen de la Victoria, Málaga, Spain \\ ${ }^{\mathrm{c}}$ Fundamental and Applied Research for Animals \& Health (FARAH), Department of Food Sciences, Faculty of Veterinary Medicine, University of Liège, Belgium
}

\section{A R T I C L E I N F O}

\section{Keywords:}

Listeria monocytogenes

Farm animals

Dissemination

Control measures

\begin{abstract}
A B S T R A C T
Listeria monocytogenes (L. monocytogenes) is a well-known pathogenic bacterium that causes the disease listeriosis in both humans and animals. Human transmission mainly occurs via ingestion of contaminated foods and specifically affects pregnant women, newborns, elderly individuals and immunosuppressed individuals. Several outbreaks have been historically associated with the consumption of fresh raw milk and unpasteurized cheese, highlighting the role of good farm hygiene measures to reduce the probability of milk contamination. $L$ monocytogenes is ubiquitous in the environment, and therefore, this bacterium is commonly found in silage, haylage, grazing pastures, crop fields, farmyards and even water. Faeces of wild animals, including gulls and rooks, have also been described as important vectors of the pathogen for farm animal contamination, as well as animal bedding, soils or feed bunk tanks, especially when animals are housed during indoor months. Milking lines, including filters, collectors, bulk tanks and other utensils in the room, have been described as important sites of bacterial detection. The ability of $L$. monocytogenes to produce biofilms and to survive in humid environments makes elimination difficult and increases its persistence in equipment and on floors, leading to high risk of milk contamination at harvest in farms. This review explores in depth the different sources of L. monocytogenes contamination described in production farms, with a special focus on ruminants, identifying the transmission vectors and analysing the applicable control measures at each stage.
\end{abstract}

\section{Introduction}

Listeria monocytogenes (L. monocytogenes) is a Gram-positive, facultatively anaerobic, rod-shaped intracellular bacterium that causes listeriosis, affecting both animals and humans. The bacterium is ubiquitous in the environment, and its natural habitat is thought to be decomposing plant material, in which it lives as a saprophyte (Schoder et al., 2012) and can multiply when temperature and humidity are optimal. The genus Listeria, family Listeriaceae, currently includes 20 species (LPSN, 2020) that are highly adapted to soil, water and plants (Linke et al., 2014). L. monocytogenes has been classified into 3 major well-conserved evolutionary divisions according to serotype, mainly based on the variation in the somatic and flagellar antigens. More than 14 serotypes have been described, with serotype $4 \mathrm{~b}$ (division I) being closely associated with human epidemics and serotype $1 / 2$ a (division I) being closely associated with contaminated foods (Borucki \& Douglas, 2003; Rasmussen et al., 1995).

L. monocytogenes infection has been described in a wide range of animal species, but farm animals are the most commonly affected (Ho et al., 2007). After ingestion, L. monocytogenes is able to penetrate the mucosa of the intestine and cause infections in humans and animals, which can include septicaemia, meningitis, encephalitis or uterine infections (Constable et al., 2016; Wiedmann et al., 1997). In animals, encephalitis is characterized by neurological signs (circling, excessive salivation and unilateral facial paralysis). In addition, eye infections, uveitis, and keratitis are also possible (Nightingale et al., 2004). Uterine infections usually lead to abortion, still birth, septicaemia in neonates or subclinical mastitis (Papić et al., 2019). The incidence rate of subclinical mastitis caused by L. monocytogenes seems to be lower in comparison with other mastitis pathogens, like Klebsiella, Escherichia-Shigella,

\footnotetext{
* Corresponding author. Instituto de Investigación Biomédica de Málaga-IBIMA, Málaga, Spain.

** Corresponding author. Instituto de Investigación Biomédica de Málaga-IBIMA, Málaga, Spain.

E-mail addresses: kriszsi@hotmail.com, cris.rdrz@gmail.com (C. Rodriguez), edugf1@gmail.com (E. García-Fuentes).

1 Equal contribution to this work.
} 
Streptococcus or Corynebacterium, but its prevalence in farms is high (Pang et al., 2018), Some animals can be latent L. monocytogenes carriers without showing any signs of disease. In these apparently healthy animals, the bacterium is frequently found in faeces and in nasal and genital secretions, acting as vectors of infection for the herd.

It has been showed that $L$. monocytogenes can produce chronic intramammary infection in clinical healthy goats, which represents an important bacterium shedding in the farms, and a source of milk contamination (Addis et al., 2019). In cows and sheep with mastitis, L. monocytogenes has been detected in their excreted milk and in their quarters and/or udders (Winter et al., 2004). While L. monocytogenes haematogenous mammary gland infection has not been ruled out, many studies consider the intramammary route more likely (Bourry et al., 1995; Tzora et al., 1998; Winter et al., 2004). Tzora et al. (1998) showed that intramammary inoculation of L. monocytogenes at levels of 1000 cfu results in a successful colonization and subclinical or mild mastitis. A further study showed how L. monocytogenes mastitis is caused by bacteria penetration in the udder through the teat canal (Winter et al., 2004). Therefore, udder faecal contamination is an important source of contamination.

L. monocytogenes is an important foodborne pathogen. Frequently, human exposure can occur through the consumption of raw, unpasteurized milk or cheese, although in the last decade, other foods have also been implicated in several outbreaks, including meatloaf, smoked fish, fermented raw sausages, or vegetables (Acciari et al., 2017; Aksono et al., 2020; Smith et al., 2018). L. monocytogenes can also cause zoonoses, albeit with less public health impact, especially in humans in close contact with or with direct exposure to infected herds, faecal particles and dust from which are spread in a windborne manner. The reported infections cause by contact include conjunctivitis and dermatitis with a papular and pustular rash, especially when the infected animals present dystocia and aborted foetuses and are handled without gloves (Constable et al., 2016). However, when infection occurs as a foodborne disease, the outcome can be fatal, especially in immunosuppressed individuals, neonates, elderly individuals and pregnant women. Fortunately, a strong decrease in the incidence of neonatal L. monocytogenes meningitis has been detected, probably due to preventive measures in pregnant women (Koopmans et al., 2017). The manifested syndromes include febrile gastroenteritis, septicaemia, abortions and central nervous system infections, such as meningitis, meningoencephalitis and rhombencephalitis (Oevermann et al., 2010).

The seasonality of L. monocytogenes in farms and their environments has been previously described, with the bacterium being more prevalent during spring and winter seasons than in fall or summer (Mohammed et al., 2019; Nightingale et al., 2005; Welshimer \& Donker-Voet, 1971). In ruminants, several factors associated with the suppression of host immunity have been identified as promoters of infection. Sudden changes in ration, extremely cold weather, overcrowding of animals indoors, prolonged periods of transport, pregnancy, parturition, lactation, or other situations of stress are often linked with listeriosis. Contamination of milk with $L$. monocytogenes is more frequently reported during winter months than in the rest of the year, perhaps due to increased exposure of animals to different sources of infection (Nightingale et al., 2005).

In addition to animal feed, surfaces and materials in close contact with farm animals, including feed bunks, water troughs, and bedding, have been described as important vectors of listeriosis in dairy farms. Furthermore, the great variety of $L$. monocytogenes serotypes found on farms has led to hypotheses regarding the introduction of the bacterium by wild or domestic animals, farm visitors and contaminated vehicles or machines (Castro et al., 2018) (Fig. 1). These findings reveal the need for specific sanitary measures against this bacterium in the immediate

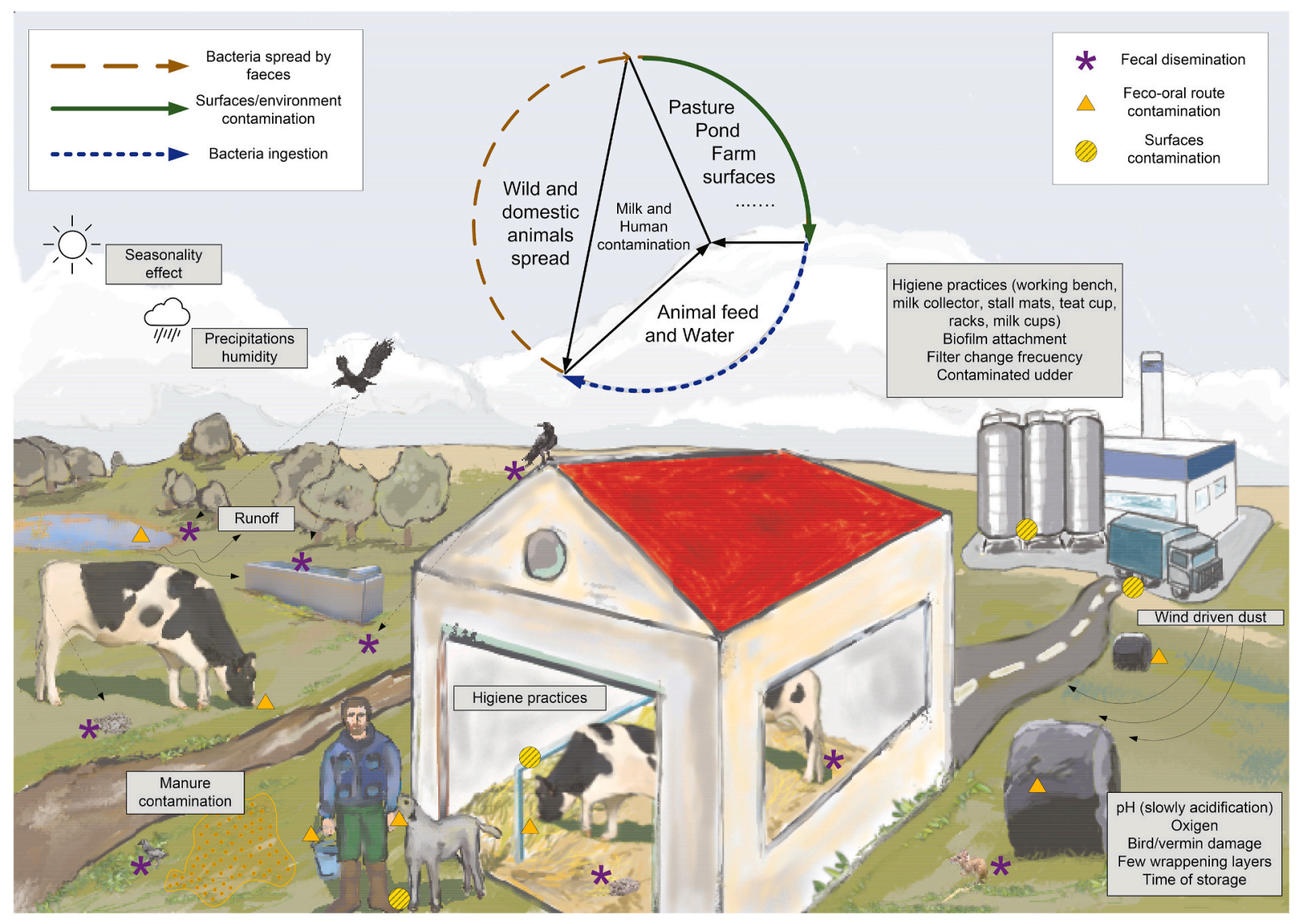

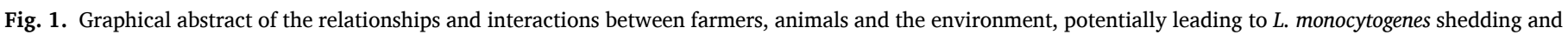
interspecies transmission. 
environments of farm animals (Mohammed et al., 2019). In this review, we investigate the ecology of $L$. monocytogenes on dairy farms and the identification of the main sources of contamination, which are essential factors for improving these control measures.

\section{L. monocytogenes in food production animals}

L. monocytogenes has been identified in almost all common types of animal production, although the most important foodborne outbreaks have been mainly associated with raw milk, unpasteurized milk and other dairy products (Shamloo et al., 2019). Dairy cattle farms harbour L. monocytogenes genotypes associated with human listeriosis outbreaks (Castro et al., 2018). Furthermore, these genotypes are also associated with several outbreaks in ruminants, including abortions in cattle (Whitman et al., 2020), encephalitis (Wiedmann et al., 1994), and rhombencephalitis (Dell'Armelina-Rocha et al., 2013). A previous study conducted in dairy cattle did not detect an association between faecal shedding of $L$. monocytogenes and lactation number or lactation day (Ho et al., 2007). Treatment against lice was found to be associated with the presence of L. monocytogenes in animal faeces, with up to $56 \%$ of animals excreting the bacterium after treatment (Ho et al., 2007). The authors hypothesized that the antiparasitic agent used could be responsible for immunosuppression in animals, as also reported in goats (Tamang et al., 1988). However, in the same study, stress after cattle manipulation was not excluded as a possible co-factor of faecal shedding of the bacterium (Ho et al., 2007).

In pigs, infection by L. monocytogenes is relatively unusual, although the bacterium is commonly detected in the faeces of healthy animals, in feed, in litter, on floors and walls, and in feed units. A recent report identified an outbreak of fatal listeriosis in fattening pigs in a pigletproducing farm in Lower Austria. Animals presented bloody and watery diarrhoea, anorexia, increased body temperature up to $40^{\circ} \mathrm{C}$, septicaemia, circulatory insufficiency and fibrino-necrotic typhilocolitis. Poor-quality maize silage contaminated with the bacterium and mycotoxins of Fusarium sp. (3000 ppb deoxinivalenol (DON) and 270 ppb zearalenone (ZEA)) was identified as the source of the infection. In this outbreak, the authors hypothesized that the immunosuppression caused by DON could contribute to the persistence and pathogenicity of L. monocytogenes in the intestine (Stein et al., 2018). However, the most common problem associated with Listeria in swine production is pork product contamination, especially because the animals can be carriers at slaughter without showing any signs of disease. Pigs that harbour L. monocytogenes on farms can carry the pathogen into the slaughterhouse and be a direct source of contamination for carcasses and meat at the slaughterhouse and in production plants (Constable et al., 2016; Hellström et al., 2010).

L. monocytogenes is able to infect most avian species (chickens, turkeys, waterfowl, geese, ducks, game birds, pigeons, parrots, etc.), although outbreaks are rare. The bacterium is more frequently reported as an opportunistic pathogen, associated with coccidiosis, infectious coryza, salmonellosis, campylobacteriosis, parasitic infections, etc. (Dhama et al., 2013). Furthermore, grow-out farm studies have shown that avian species are important potential vectors for $L$. monocytogenes contamination of the processing environment (Rothrock et al., 2017).

\section{Animal feed as a source of L. monocytogenes contamination}

Animals exposed to L. monocytogenes by feed can contract infection or act as carriers of the bacterium without showing any signs of disease, excreting the bacterium in the faeces (Castro et al., 2018). These animals constitute an important reservoir that must be controlled since faecal contamination during milking can lead to the presence of the bacterium in the bulk tank and therefore in the raw milk. Recently, an important epidemiological link between silage, water sources, subclinical mastitis and $L$. monocytogenes contamination in dairy farms was reported (Papić et al., 2019). It has been shown that the quality of feedstuffs provided (especially during indoor seasons) has a direct influence on the immune status of the animals and therefore on the acquisition of the infection (Nightingale et al., 2005). Poor-quality or poorly preserved silage was identified as a direct source of $L$. monocytogenes contamination in cattle farms (Castro et al., 2018; Nucera et al., 2016). High quality silage is safe for the animal, for the consumer, for the environment, and an excellent feed, as the microbes in properly made and managed silages have probiotic effects on livestock (Driehuis and Elferink, 2000). Well preserved silages are characterized by a rapid acidification, with a final $\mathrm{pH}$ ranging between 3.7 and 4.7, in function of the type forage (legume, grass or corn silage), and with an anaerobic atmosphere inside the silo (Limin Kung et al., 2018). When oxygen is available or when the $\mathrm{pH}$ is above 4.7, undesirable microorganisms can proliferate and produce hazards to animal or human health. These microorganisms include L. monocytogenes, Bacillus cereus, C. botulinum, or even molds with mycotoxins production, among others. Other yeast or butyric acid bacteria are not directly dangerous for animal health, but they produce a reduction in the quality of the silage (Santos et al., 2015).

In sheep and goats, contaminated silage has been reported to be a source of infection and to contribute to massive contamination of the farm and milk processing environment (Schoder et al., 2012). The detection of $L$. monocytogenes seems to be relatively high in herds fed component feed and leftover feed (Constable et al., 2016).

Access to pastures is an important and beneficial practice for animals in terms of physical health, animal welfare and handling. In terms of physical health, cattle in pastures suffer less from lameness, hoof pathologies, hock lesions, mastitis, uterine disease and mortality than confined cattle (Arnott et al., 2017). Animal behaviours, including agonistic, lying or oestrous behaviours, and synchronicity are better in pasture-based cows than in confined cows (Mee \& Boyle, 2020). Although the milk production can be somewhat reduced, other economic factors, including labour for animal care, manure handling, forage management, and cow culling rates, also favour outdoor management (White et al., 2002). Furthermore, animals with access to and maintained on pastures are associated with a decreased rate of L. monocytogenes faecal shedding (Nightingale et al., 2005), even though the bacterium is ubiquitous in the environment and some factors can lead to its high abundance in grass and other soil samples (Coblentz \& Akins, 2018).

\subsection{Fermented silage and its impact on listeriosis}

Ensilation is a process for conservation of forages in the wet state through acidification, which prevents the continued occurrence of plant life processes and undesirable microbial activity. Unlike haymaking, this process is independent of atmospheric conditions and preserves the humid state through acidification. For good quality and good preservation of silage, rapid acidification by acetic and lactic fermentation and maintenance of anaerobic conditions are necessary (Driehuis and Elferink, 2000). L. monocytogenes, which is a part of the normal bacterial composition of grass, can proliferate when there is aerobic spoilage and deterioration of silage during storage or feeding (by hand-tying a perforated bag, with holes made by birds, vermin, etc.) (Coblentz \& Akins, 2018; Fenlon, 1986). Big bales of silage are at great risk for L. monocytogenes contamination due to the low density and due to the high probability of mechanical damage to the plastic covering (Schoder et al., 2012). To reduce this risk, it is important to use high-quality polyethylene stretch films and to increase the number of wrapping layers to 6 or even 8 (Nucera et al., 2016), and the pH can be checked before use for control of contamination (4/4,5 or below) (Sanaa et al., 1993). A previous study investigated the environmental factors that can directly influence the presence of this bacterium in fermented silages (Pauly \& Tham, 2003). In this study L. monocytogenes was not detected in untreated silages after 90 days or more, even at a $\mathrm{pH}$ of 4.9 or higher. This finding indicates that the time of storage may be one of the most important factors for reducing bacterial counts, which could be 
combined with intensive fermentation as an optimal measure to prevent the survival of the bacterium. A further study showed how the silage stored in a bunker was associated with an increased rate of L. monocytogenes faecal shedding, while bag storage showed the opposite effect (Nightingale et al., 2005).

Additives such as formic acid or lactic acid bacteria with cellulolytic enzymes had a negative influence on $L$. monocytogenes persistence when applied in wet silages and wilted crops, respectively. Further studies described the effects of bacteriocins produced by Streptococcus bovis HC5 or Pediococcus acidilacti in maize silages and demonstrated their effectiveness for L. monocytogenes control as well as for improvement of the fermentation process (Amado et al., 2016; Mantovani and Russell, 2003). Furthermore, a mathematical model investigated Listeria growth in aerobically deteriorated silage bales (Ruxton \& Gibson, 1995). The authors found that the puncture size directly affected the increase in $\mathrm{pH}$; small punctures were more harmful when bales were stored for a long time than when bales were stored for a short time.

Several studies have investigated the contamination of feed for milk cows (Table 1). Nucera et al. (2016) detected L. monocytogenes in 6 out of $80(7,5 \%)$ silages, with most of the positive samples belonging to mouldy areas. One previous study described that cattle are more exposed to L. monocytogenes through contaminated feed than small ruminants. However, it is likely that this continuous exposure improves their immunity to the infection (Nightingale et al., 2004). While feeding with silage is normal on dairy farms, it is not such a frequent practice in calf-cow operations, which seems to explain the relatively low prevalence of the bacterium in these types of farms (Mohammed et al., 2010).
In Europe, the introduction of baled silage was marked by an increase in listeriosis cases in small ruminants (Coblentz \& Akins, 2018; McDonald et al., 1991). Grass silage has been described as an important source of listeriosis in sheep (Gronstol, 1979). In clamp silage, the reported prevalence ranged between 2.5 and 5.9\%, while in big-bale silages, the percentage of positive samples was between $22.2 \%$ and $44 \%$, when the silage had moulds (Fenlon, 1986). Other consequences of silage contamination in ruminants are eye infections and keratitis, linked to direct inoculation of the bacterium in the conjunctiva during intake (Nightingale et al., 2004).

\subsection{Pasture, grains and manure}

Different environmental factors can influence the natural animal contamination of pasture, grass and silages, and unfortunately, these factors are often the most difficult ones to control. Recently, listeriosis contamination in farm environments was attributed in part to the use of products from wastewater treatment and animal manure in soils to improve their physical and organic properties (Coblentz \& Akins, 2018; McDonald et al., 1991). It has been shown that genus Listeria is able to survive in both solid manure piles and in slurry samples for several weeks. Furthermore, bacterial viability is related to weather and pile size (Biswas et al., 2018). Different possibilities of treatment methods for manure have been proposed in order to reduce the load of undesirable microorganisms, some of them include: i) composting, ii) aeration, iii) biogas production, iv) chemical disinfection v) pasteurization, vi) lactic acid fermentation and vii) desiccation, among others. (Scheinemann

Table 1

Previous research studies investigating the presence of $L$. monocytogenes in animal feedstuffs and feeding surfaces in ruminant farms.

\begin{tabular}{|c|c|c|c|c|c|c|}
\hline Type of sample & Animal & Type of production & $\begin{array}{l}\text { Geographical } \\
\text { localization }\end{array}$ & $\begin{array}{l}\text { Number of farms } \\
\text { tested }\end{array}$ & $\begin{array}{l}\text { Prevalence in animal } \\
\text { faeces }\end{array}$ & References \\
\hline Feeding surfaces & Cattle & Milking cows & Finland & 3 & $25.9 \%(34 / 131)$ & Castro et al. (2018) \\
\hline \multirow[t]{2}{*}{ Feed bunks } & & & Central New York State & 50 & $65 \%(158 / 242)$ & $\begin{array}{l}\text { Mohammed et al. } \\
\text { (2009) }\end{array}$ \\
\hline & & Feedlot operations & $\begin{array}{l}\text { Central and southern } \\
\text { California }\end{array}$ & 25 & $2.5 \%(3 / 121)$ & $\begin{array}{l}\text { Mohammed et al. } \\
\text { (2010) }\end{array}$ \\
\hline Cow feed & & Feedlot operations & $\begin{array}{l}\text { Central and southern } \\
\text { California }\end{array}$ & 25 & $1.7 \%(118)$ & $\begin{array}{l}\text { Mohammed et al. } \\
\text { (2010) }\end{array}$ \\
\hline Feed concentrate & & Milking cows & Finland & 3 & $16 \%(4 / 25)$ & Castro et al. (2018) \\
\hline Produced fields & General & Soy bean and corn crops & $\begin{array}{l}\text { Hannover Virginia } \\
\text { (USA) }\end{array}$ & 12 & $40 \%(8 / 20)$ & Welshimer, $1968^{10}$ \\
\hline $\begin{array}{l}\text { Feedstuffs (haylage and } \\
\text { silage) }\end{array}$ & Ruminants & Dairy and meat farms & New York State & 52 & $16.8 \%(87 / 516)$ & $\begin{array}{l}\text { Nightingale et al., } \\
\text { 2004; }\end{array}$ \\
\hline $\begin{array}{l}\text { Grazing pastures, crop fields } \\
\text { and farmyard }\end{array}$ & & & & & $23.8 \%(120 / 504)$ & \\
\hline Cut grass & Cattle & Cow-calf operations & $\begin{array}{l}\text { Central and southern } \\
\text { California }\end{array}$ & 25 & $5.3 \%(\mathrm{n}=132)$ & $\begin{array}{l}\text { Mohammed et al. } \\
\text { (2010) }\end{array}$ \\
\hline \multirow[t]{2}{*}{ Pasture } & Ruminants & Dairy farm & Australia & 7 & $7 \%(1 / 14)$ & $\begin{array}{l}\text { MacDade and Hall, } \\
1964\end{array}$ \\
\hline & Cattle & Cow pasture & Burgundy (France) & - & $17 \%(9 / 53)$ & $\begin{array}{l}\text { Locatelli et al. } \\
\text { (2013) }\end{array}$ \\
\hline \multirow[t]{2}{*}{ Produced fields } & General & $\begin{array}{l}\text { Proximity to pastures and grass } \\
\text { field }\end{array}$ & New York State & - & $15 \%(88 / 588)$ & $\begin{array}{l}\text { Strawn et al. } \\
(2013)\end{array}$ \\
\hline & & $\begin{array}{l}\text { Agricultural fields, soils, } \\
\text { animal-inhabited area }\end{array}$ & India & - & $5.4 \%(7 / 130)$ & $\begin{array}{l}\text { Moshtaghi et al. } \\
\text { (2003) }\end{array}$ \\
\hline Cow feed and pasture & Cattle & Dairy farm & Maryland & 1 & $7.1 \%(1 / 14)$ & Pang et al. (2017) \\
\hline Pasture and pelleted ration & & & Uruguay & 1 & $20 \%(1 / 5)$ & Matto et al. (2017) \\
\hline \multirow[t]{7}{*}{ Silage } & & Milking cows & Central New York State & 50 & $30 \%(72 / 240)$ & $\begin{array}{l}\text { Mohammed et al. } \\
\text { (2009) }\end{array}$ \\
\hline & & & Finland & 3 & $16.7 \%(21 / 126)$ & Castro et al. (2018) \\
\hline & & Dairy farms & Tennessee & 4 & $6.2 \%(6 / 97)$ & $\begin{array}{l}\text { Murinda et al. } \\
\text { (2004) }\end{array}$ \\
\hline & & & Japan & 20 & $10 \%(2 / 20)$ & Takai et al. (1990) \\
\hline & & Cows producing milk & Italy & 20 & $7.5 \%(6 / 80)$ & $\begin{array}{l}\text { Nucera et al. } \\
(2016)\end{array}$ \\
\hline & Sheep & Agricultural environment & Scotland & - & $\begin{array}{l}22 \%-2.5 \% \text { (clamp/big } \\
\text { bales silage) } \\
44 \% \text { in silages with } \\
\text { molds (sheep) }\end{array}$ & Fenlon et al., 1985 \\
\hline & $\begin{array}{l}\text { Small } \\
\text { ruminants }\end{array}$ & $\begin{array}{l}\text { Ovine and caprine milking } \\
\text { farms }\end{array}$ & Austria & 53 & $8.6 \%$ & $\begin{array}{l}\text { Schoder et al. } \\
\text { (2011) }\end{array}$ \\
\hline
\end{tabular}


et al. (2015); Roberts et al., 2016; Scheinemann et al. (2015); Heinonen-Tanski et al., 2006). However, all of these methods have different technical and hygiene-related limitations, as well as important associated costs (Heinonen-Tanski et al., 2006). Therefore, their use usually depends on the form of manure, the size of the animal unit and the available resources for exploitation. For example, Scheinemann et al. (2015) described how macrobiotic shift during lactic acid fermentation of cow manure or sewage sludge was a low-cost method that inactivated L. monocytogenes and other pathogens after 3 days of fermentation, even at $27{ }^{\circ} \mathrm{C}$. Regarding drying treatments, previous studies showed how L. monocytogenes is able to survive in manure with a water content less than $30 \%$, although bacterial multiplication is limited (Kim \& Jiang, 2010; Himathongkham and Riemann, 1999). This may be due to the inherent resistance to desiccation through the thick peptidoglycan wall possessed by Gram-positive bacteria (Roberts et al., 2016). In this context, potential serotype-specific resistance to desiccation or humidity fluctuations has been described for serotype $1 / 2 \mathrm{~b}$ strains at up to $75 \%$ relative humidity (Zoz et al., 2017). Further studies have described how Gram-positive bacteria are more resistant to stress factors than Gram-negative bacteria when they are exposed to unfavourable environmental conditions (MacDade and Hall, 1964; Bale et al., 1993). Different metabolic pathways have been related with the survival of the bacterium in adverse conditions. L. monocytogenes is able to grow in osmotically stressful environments using compatible solutes. The bacterium accumulates glycine betaine osmolite intracellularly when grown under osmotic stress, and this accumulation occurs by transport from the medium rather than novo synthesis (Ko et al., 1994). Branched-chain fatty acid also responds to the environmental stress by adjusting membrane fluidity (Zhu et al., 2005). Oxygen limitation in the medium also induces acid tolerance response and survival via the activation of the acid glutamate system (Roberts et al., 2020; Sewell et al., 2015).

The presence of L. monocytogenes in treated manure without Salmonella contamination has also been described, indicating that Enterobacteriaceae are not the sole indicators of safety in waste treatment (Bonetta et al., 2011). General recommendations that could be applied for all farms are to avoid application of raw animal manure in pastures, lands and crops; to correctly cover the manure to prevent runoff in the environment; to store the manure separately and only by batch; and to introduce anaerobic digestion of waste (Manyi-Loh et al., 2016). Finally, it is necessary to reduce, as much as possible, the microbial load in animals during feeding and breeding, which will have a direct impact on the bacterial levels in excreted animal faeces.

Several studies have investigated the presence of $L$. monocytogenes in animal feed, including pastures, cut-grass and crops. Differences can be observed in relation to the prevalence of this bacterium in soils, but these differences are probably due to a seasonal effect or due to the use of different sampling strategies and culture methods. Pastures are extensive areas in which the presence of bacteria is not evenly distributed and varies strongly depending on the area studied. Regarding culture methods, sensitivity depends on the use of enrichment media or other rapid molecular techniques (Locatelli et al., 2013). A possible seasonal variation in the frequency of bacterial occurrence in soils, with isolation not observed during autumn months, has also been described (Welshimer \& Donker-Voet, 1971).

The two first studies carried out in the late sixties and early seventies in Virginia observed the presence of $L$. monocytogenes in soybean crops and in pieces of stalks, leaves and tassels of corn crops, with prevalence ranging between $66.7 \%$ and $91.7 \%$ (Welshimer, 1968; Welshimer \& Donker-Voet, 1971). In the second study, the bacterium was isolated only during the spring collection, suggesting a possible seasonal effect. According to this finding, Nightingale et al. (2005) also reported a seasonal fluctuation in cattle farm soils located in the state of New York, with higher levels of bacteria observed in spring and winter months than in the rest of the year. In livestock farms in Korea, the presence of L. monocytogenes was observed in only 3 soils out of 2018 samples tested $(0.15 \%)$. However, all of the isolates found presented virulence genes and phenotypic resistance to antibiotics (Oh et al., 2016). In French soils, L. monocytogenes was reported with a prevalence of $27 \%$ only in cow pasture samples, but with levels that did not exceed $10^{4} \mathrm{cfu} / \mathrm{g}$ (Locatelli et al., 2013). The bacterium was not isolated from cultivated soils, meadows or forest soils, suggesting that cattle also have an important role in the spread and contamination in the environment. In this context, a further investigation showed one case of brainstem encephalitis caused by L. monocytogenes in a 2 -y-old cross-breed bull, and the source of infection was finally identified as the pasture where the bull grazed. Surprisingly, this pasture had not been previously fertilized with manure or sewage sludge, indicating that the bacterium in the soil originated from cattle faecal shedding (Matto et al., 2017). These findings are consistent with other studies in which authors suggested that cattle are the main source of contamination by faecal deposition during grazing (Mohammed et al., 2010).

\section{Birds, wild animals and other environmental factors}

The contamination of soils can contribute to the spread of the bacterium through farm animals or other wild animals, which can act as additional important vectors for bacterial transmission (Table 2). The access of birds to feed storage in farms has also been associated with the contamination of cereals, grains and straw (Konosonoka et al., 2012). Wild birds living close to agricultural environments can act as carriers of L. monocytogenes, and they can contribute to the spread of bacteria through their faeces in pastures, soils, water and other feedstuffs (Schoder et al., 2012). Seagulls feeding at sewage facilities as well as rooks (but to a lesser extent) have been previously identified as carriers of $L$. monocytogenes in faeces, and their bacterial load is associated with the nesting season and the peak period for listeriosis in sheep (Fenlon, 1986). A previous study investigated the presence of several pathogens in the environments of four dairy farms. The authors revealed the presence of $L$. monocytogenes in bird droppings, mostly in geese, with a prevalence of $10 \%$. However, none of the samples tested from flies, rats and birds were positive for the bacterium, which confirms the fundamental role of birds as vectors of this pathogen (Murinda et al., 2004).

Further studies have highlighted the influence of environmental conditions on the spread of bacteria, especially in mixed farms, where there is a risk of not only crop contamination but also of contamination of grass destined for fermentation to be converted to silage. Pang et al. (2017) showed that seasonality was not the most important factor for the dissemination of listeria species in soils, but abundant precipitation and high wind speed acted as vectors for pathogen transmission via run-off and windborne dust. A further study found that precipitation and the occurrence of alternating freezing and thawing temperatures before soil sample collection were predictors for the presence of genus Listeria (Ivanek et al., 2009). In this context, a prevention strategy could be to postpone mowing if these weather conditions occur in the two days prior to harvest. Moisture also seems to influence the prevalence of L. monocytogenes in soils and vegetation, with the bacterium being more prevalent in moist pastures and grassy fields (Strawn et al., 2013). However, even though soil pasture contamination may be a source of contamination (Nightingale et al., 2004), it has been suggested that management systems that include pasture grazing reduce the prevalence of $L$. monocytogenes shedding (Nightingale et al., 2005). This is because although it does occur, exposure occurs less frequently in pastures than when the animals are housed in a stable, in contact with many other potential sources of contamination (Table 2).

\section{Water and farm animal environments as sources of L. monocytogenes contamination}

High farm density during indoor months is an important factor for L. monocytogenes shedding and infection in farms. This overcrowding favours the spread of the bacterium between animals and the contamination of several surfaces, including feed bunks, water, and farm soils. In 
Table 2

Occurrence of $L$. monocytogenes in farm animal environment: water, bedding, soils, faeces and manure.

\begin{tabular}{|c|c|c|c|c|c|c|}
\hline Type of sample & Animal & Type of production & $\begin{array}{l}\text { Geographical } \\
\text { localization }\end{array}$ & $\begin{array}{l}\text { Number of } \\
\text { farms tested }\end{array}$ & $\begin{array}{l}\text { Prevalence in animal } \\
\text { faeces }\end{array}$ & References \\
\hline \multirow[t]{2}{*}{ Water } & Ruminants & Dairy and meat farms & New York State & 52 & $19.7 \%(100 / 508)$ & $\begin{array}{l}\text { Nightingale et al., } \\
\text { 2004; }\end{array}$ \\
\hline & Cattle & Dairy farms & Dairy farms & 16 & $17 \%(6 / 36)$ & Fox et al., 2009 \\
\hline Water trough surface & & Milking cows & Finland & 3 & $32 \%(48 / 150)$ & $\begin{array}{l}\text { Castro et al. } \\
\text { (2018) }\end{array}$ \\
\hline \multirow[t]{5}{*}{ Water trough } & & Dairy farms & New York State & 1 & $64.3 \%$ & $\begin{array}{l}\text { Latorre et al. } \\
(2011)\end{array}$ \\
\hline & & Milking cows & $\begin{array}{l}\text { Central New York } \\
\text { State }\end{array}$ & 50 & $66 \%(160 / 242)$ & $\begin{array}{l}\text { Mohammed et al. } \\
\text { (2009) }\end{array}$ \\
\hline & & $\begin{array}{l}\text { Cow-calf and feedlot } \\
\text { operations }\end{array}$ & $\begin{array}{l}\text { Central and southern } \\
\text { California }\end{array}$ & 25 & $\begin{array}{l}0.8 \%(\mathrm{n}=121) \\
3.1 \%(\mathrm{n}=32)\end{array}$ & $\begin{array}{l}\text { Mohammed et al. } \\
\text { (2010) }\end{array}$ \\
\hline & & Milking cows & Finland & 3 & $4.8 \%(4 / 83)$ & $\begin{array}{l}\text { Castro et al. } \\
(2018)\end{array}$ \\
\hline & & Dairy farm & Tennessee & 4 & $1.1 \%(1 / 92)$ & Murinda et al. \\
\hline Lagoon cattle & & & & & $7.4 \%(7 / 94)$ & (2004) \\
\hline \multirow[t]{2}{*}{ Water ponds } & & Cow-calf operations & $\begin{array}{l}\text { Central and southern } \\
\text { California }\end{array}$ & 25 & $6.5 \%(\mathrm{n}=31)$ & $\begin{array}{l}\text { Mohammed et al. } \\
\text { (2010) }\end{array}$ \\
\hline & Ruminants & Dairy farm & Australia & 7 & $6.5 \%(2 / 31)$ & $\begin{array}{l}\text { MacDade and } \\
\text { Hall, } 1964\end{array}$ \\
\hline Water tank & $\begin{array}{l}\text { Small } \\
\text { ruminants }\end{array}$ & $\begin{array}{l}\text { Sheep and lamb's } \\
\text { meat farm }\end{array}$ & Switzerland & 1 & $10 \%(1 / 10)$ & $\begin{array}{l}\text { Dreyer et al. } \\
(2015)\end{array}$ \\
\hline $\begin{array}{l}\text { Water various (including water pipe, water } \\
\text { trough, water pond, water household }\end{array}$ & Cattle & Dairy farm & Slovenia & 1 & $57,1 \%(4 / 7)$ & Papić et al., 2019 \\
\hline Exit point from irrigation ditch & & Cow-calf operations & $\begin{array}{l}\text { Central and southern } \\
\text { California }\end{array}$ & 25 & $14.3 \%(n=15)$ & $\begin{array}{l}\text { Mohammed et al. } \\
\text { (2010) }\end{array}$ \\
\hline Milking line rinse water & & Milking cows & Finland & 3 & $3.1 \%(1 / 32)$ & $\begin{array}{l}\text { Castro et al. } \\
(2018)\end{array}$ \\
\hline Working bench & $\begin{array}{l}\text { Small } \\
\text { ruminants }\end{array}$ & $\begin{array}{l}\text { Ovine and caprine } \\
\text { milking farms }\end{array}$ & Austria & 53 & $4.7 \%$ & $\begin{array}{l}\text { Schoder et al. } \\
\text { (2011) }\end{array}$ \\
\hline Bedding (sawdust) & Cattle & Milking cows & United Kingdom & 44 & $31.7 \%(13 / 44)$ & Bradley et al. \\
\hline Bedding (sand) & & & & 41 & $58.5 \%(24 / 41)$ & (2018) \\
\hline Bedding (recycled manure) & & & & 40 & $15 \%(6 / 40)$ & \\
\hline Bedding (sand, wood shavings or straw) & & Dairy farm & Tennessee & 4 & $14.4 \%(13 / 90)$ & $\begin{array}{l}\text { Murinda et al. } \\
\text { (2004) }\end{array}$ \\
\hline Bedding & & Milking cows & $\begin{array}{l}\text { Central New York } \\
\text { State }\end{array}$ & 50 & $55 \%(132 / 240)$ & $\begin{array}{l}\text { Mohammed et al. } \\
\text { (2009) }\end{array}$ \\
\hline Bedding in barn & Cattle & Milking cows & Finland & 3 & $23.5 \%(16 / 68)$ & Castro et al. \\
\hline Bedding storage & & & & & $10.4 \%(5 / 48)$ & (2018) \\
\hline \multirow[t]{5}{*}{ Soil } & Ruminants & Dairy and meat farms & New York State & 52 & $23.8 \%(120 / 504)$ & $\begin{array}{l}\text { Nightingale et al., } \\
\text { 2004; }\end{array}$ \\
\hline & Cattle & $\begin{array}{l}\text { Cow-calf and feedlot } \\
\text { operations }\end{array}$ & $\begin{array}{l}\text { Central and southern } \\
\text { California }\end{array}$ & 25 & $\begin{array}{l}0.7 \%(\mathrm{n}=972) \\
5.3 \%(\mathrm{n}=132)\end{array}$ & $\begin{array}{l}\text { Mohammed et al. } \\
\text { (2010) }\end{array}$ \\
\hline & $\begin{array}{l}\text { Small } \\
\text { ruminants }\end{array}$ & $\begin{array}{l}\text { Sheep and lamb's } \\
\text { meat farm }\end{array}$ & Switzerland & & $10 \%(1 / 10)$ & $\begin{array}{l}\text { Dreyer et al. } \\
(2015)\end{array}$ \\
\hline & $\begin{array}{l}\text { Cattle and } \\
\text { pigs }\end{array}$ & $\begin{array}{l}\text { Livestock (pigs and } \\
\text { cattle) farms }\end{array}$ & Korea & 25 & $0.4 \%(3 / 680)$ & Oh et al. (2016) \\
\hline & Cattle & Dairy farms & Dairy farms & 16 & $3 \%(1 / 35)$ & Fox et al., 2009 \\
\hline Floor swabs & $\begin{array}{l}\text { Small } \\
\text { ruminants }\end{array}$ & $\begin{array}{l}\text { Ovine and caprine } \\
\text { milking farms }\end{array}$ & Austria & 53 & $7.9 \%$ & $\begin{array}{l}\text { Schoder et al. } \\
\text { (2011) }\end{array}$ \\
\hline Floors in the parlor pit and storage & Cattle & Cow dairy farm & New York State & 1 & $20 \%(2 / 10)$ & $\begin{array}{l}\text { Latorre et al. } \\
\text { (2011) }\end{array}$ \\
\hline Soil (waiting area floor) & & Milking cows & Finland & 3 & $56.6 \%(16 / 31)$ & Castro et al. \\
\hline Soil (milking room floor) & & & & & $42.1 \%(16 / 38)$ & (2018) \\
\hline Soil (milking station floor) & & & & & $47.5 \%(38 / 80)$ & \\
\hline \multirow[t]{3}{*}{ Wild animals } & & Cow-calf operations & $\begin{array}{l}\text { Central and southern } \\
\text { California }\end{array}$ & 25 & $2.5 \%(n=40)$ & $\begin{array}{l}\text { Mohammed et al. } \\
\text { (2010) }\end{array}$ \\
\hline & & Dairy farm & Tennessee & 4 & $10 \%(2 / 20)$ & $\begin{array}{l}\text { Murinda et al. } \\
\text { (2004) }\end{array}$ \\
\hline & General & $\begin{array}{l}\text { Agricultural } \\
\text { environment }\end{array}$ & Scotland & - & $\begin{array}{l}8.3 \%(23 / 275) \\
\text { (gulls) } \\
9.8 \%(12 / 123) \\
\text { (rooks) }\end{array}$ & Fenlon et al., 1985 \\
\hline $\begin{array}{l}\text { Fecal slurry/pats } \\
\text { Calf fecal swabs }\end{array}$ & Cattle & Dairy farm & Tennessee & 4 & $\begin{array}{l}14.3 \%(14 / 98) \\
1.2 \%(1 / 86)\end{array}$ & $\begin{array}{l}\text { Murinda et al. } \\
\text { (2004) }\end{array}$ \\
\hline \multirow[t]{6}{*}{ Fecal samples } & Ruminants & Dairy and meat farms & New York State & 52 & $20.3 \%(107 / 528)$ & $\begin{array}{l}\text { Nightingale et al., } \\
\text { 2004; }\end{array}$ \\
\hline & & Dairy farm & Australia & 7 & $6 \%(1 / 16)$ & $\begin{array}{l}\text { MacDade and } \\
\text { Hall, } 1964\end{array}$ \\
\hline & Cattle & Dairy farms & Dairy farms & 16 & $12 \%(4 / 34)$ & Fox et al., 2009 \\
\hline & & Cow dairy farm & New York State & 1 & $6 \%(57 / 935)$ & $\begin{array}{l}\text { Latorre et al. } \\
\text { (2011) }\end{array}$ \\
\hline & & $\begin{array}{l}\text { Cow-calf and feedlot } \\
\text { operations }\end{array}$ & $\begin{array}{l}\text { Central and southern } \\
\text { California }\end{array}$ & 25 & $0.3 \%-3.7 \%$ & $\begin{array}{l}\text { Mohammed et al. } \\
\text { (2010) }\end{array}$ \\
\hline & & & & & & tinued on next page) \\
\hline
\end{tabular}


Table 2 (continued)

\begin{tabular}{|c|c|c|c|c|c|c|}
\hline Type of sample & Animal & Type of production & $\begin{array}{l}\text { Geographical } \\
\text { localization }\end{array}$ & $\begin{array}{l}\text { Number of } \\
\text { farms tested }\end{array}$ & $\begin{array}{l}\text { Prevalence in animal } \\
\text { faeces }\end{array}$ & References \\
\hline Manure & & Feedlots & Australia & 5 & $16 \%-35 \%$ & Klein et al., 2010; \\
\hline Manure & Cattle & $\begin{array}{l}\text { Anaerobic digestion } \\
\text { plant }\end{array}$ & Italy & 1 & $20 \%(1 / 5)$ & $\begin{array}{l}\text { Bonetta et al. } \\
\text { (2011) }\end{array}$ \\
\hline
\end{tabular}

this context, it has been reported that contaminants in cheese-making facilities may come directly from the external farm environment (Fox et al., 2011). Establishing protection zones along surface watercourses, within farms and in buffer zones around farms has been shown to be effective in reducing contamination (FAO, 2020).

\subsection{Water and farm soils}

Water has been identified as an important source of $L$. monocytogenes contamination in dairy farms. The bacterium was detected in water pipes (barn), water troughs (barn), and water ponds and even in water from household samples and was directly associated with subclinical listerial mastitis, even though the bacterial counts in these samples were low (Papić et al., 2019). A further study showed that the bacterium was present with high prevalence at exit points from irrigation ditches, but its presence at entry points was highly unusual. Therefore, the authors hypothesized that water and water trough contamination in farms probably comes from the animals themselves (Mohammed et al., 2010). In water troughs, the detection of the bacterium has been associated with the presence of biofilms (Latorre et al., 2011).

Previous detection of $L$. monocytogenes in pond and soil samples and its correlation with its in cattle indicates that farm environments are another source of animal contamination (Table 2). In general, the prevalence of the bacterium in soils reaches $6 \%$, being detected frequently in September and in agricultural land and urban environments (Linke et al., 2014). Furthermore, soil contamination in farms probably ends in water ponds, in which a prevalence of $L$. monocytogenes of up to $6.5 \%$ has been observed (Mohammed et al., 2010). During an outbreak that occurred in 2014 in a Swiss sheep-fattening farm, L. monocytogenes was detected in soil samples and water tanks, but all of the animal faeces were negative for the bacterium. Furthermore, the environmental contamination disappeared after thorough cleaning of pens and barns. These findings suggested that farm environment hygiene is crucial for the control of Listeria outbreaks (Dreyer et al., 2015). After drinking contaminated water, cattle become vectors for L. monocytogenes shedding on the farm and in the environment, perpetuating the bacterial infection cycle (Latorre et al., 2011).

If soils are contaminated with the bacterium, it is not surprising that shoes play a role in bacterial dissemination. The work boots of farmers, veterinarians or visitors have also been described as vectors for L. monocytogenes transmission. A previous study isolated genus Listeria and $L$. monocytogenes with frequencies of $51 \%$ and $15.7 \%$, respectively. The authors also suggested the role of a veterinarian in bacterial transmission among farms based on pulsotype results (Schoder et al., 2012).

\subsection{Bedding}

The type and microbial contents of bedding have a direct impact on animal health and milk quality. Traditionally, materials used for bedding include sawdust, hay, fresh and recycled bedding sand, calcium carbonate, rubbers and mats. Recently, the use of recycled manure solids obtained by mechanical separation of manure removed from dairy cows' housing systems was also introduced. The characterization of this material has revealed that it can be successfully used without specifically favouring the growth of environmental bacteria compared with other common bedding sources (Husfeldt et al., 2012). A recent study isolated L. monocytogenes in higher proportions from sand (up to $58,5 \%$ ) than from sawdust (31.7\%) or recycled manure solid-based (15\%) bedding, even though the latter presented significantly higher total bacterial counts. The authors suggested that the high counts of $L$. monocytogenes in sand were due to previous contamination of the soil or to low frequency of bed replenishment, but this contamination could not be related to the presence of the bacterium in milk (Bradley et al., 2018). With regard to bedding residues, the removal of heaps of livestock bedding waste from animal pens to a secondary location with a higher temperature has been described as a simple method for reducing pathogen levels in solid farm wastes (Hutchison et al., 2005).

\subsection{Farm surfaces}

The existence of persistent niches of L. monocytogenes on farm surfaces, including floors, feeding surfaces and water surfaces, has been described, and these niches increase oral exposure to the bacterium (Castro et al., 2018). Insufficient lighting of milking parlours has been associated with an increased presence of the bacterium in the facilities, perhaps because this condition hinders the cleaning and disinfection process (Sanaa et al., 1993). The ability of the bacterium to produce biofilms and adhere to several surfaces constitutes another important problem, especially in animal feeders, which are susceptible to wear on a regular basis. L. monocytogenes has the capacity to form biofilms on plastic, rubber and stainless-steel materials, which are frequently found in milking equipment and other farm equipment (Latorre et al., 2010). Once attached, if the environment is humid, the bacterium finally finds favourable conditions for growth (Lakicevic et al., 2015). In a recent study (Ripolles-Avila et al., 2020), the efficacy of an enzymatic detergent for the detachment of $L$. monocytogenes biofilm cells from surfaces was shown; the efficiency was enhanced when the number of treatment cycles was increased. However, after this intervention, the authors highlighted the need for further disinfection, which also improved the global efficacy in the elimination of biofilms. Correct and frequent cleaning of farm surfaces, especially during winter months when the animals are crowded, is an essential practice to reduce bacterial multiplication in the stable environment.

\section{Milking and raw-milk contamination}

Milk is especially susceptible to bacterial proliferation, and contamination during and after milking is frequent. Poor herd hygiene and poor milking hygiene can facilitate the transmission of the bacterium from the environment to the milk bulk tank. The presence of L. monocytogenes in milk has been associated with its presence in faecal samples and is directly correlated with animal housing during cold months (Husu, 1990) and with poor quality of silage (Sanaa et al., 1993). It has been shown that $L$. monocytogenes is more prevalent in faecal samples than in milk samples (Table 3), highlighting the importance of these animals as active reservoirs of the bacterium (Mohammed et al., 2019).

L. monocytogenes has been detected in milk bulk tanks (Table 4) and in milk-vending machines, with a prevalence of $0.5 \%$ and at levels $<10$ $\mathrm{cfu} \mathrm{ml}^{-1}$ (Dalzini et al., 2016). Even though the prevalence and pathogen concentration are low, the presence of the bacterium represents an important risk for human foodborne infection, especially when unpasteurized dairy products are consumed (Osman et al., 2014).

Faecal contamination is the most common route of milk bulk tank contamination. Many factors can contribute to the bacteria reaching raw milk at this stage. Practices of pre-milking teat disinfection or the use of 
Table 3

Presence of $L$. monocytogenes in dairy farms: prevalence in animal faeces and raw milk.

\begin{tabular}{|c|c|c|c|c|c|c|c|}
\hline Animal & $\begin{array}{l}\text { Geographical } \\
\text { localization }\end{array}$ & $\begin{array}{l}\text { Number of } \\
\text { Farms/herds } \\
\text { tested }\end{array}$ & Type of production & Period & $\begin{array}{l}\text { Prevalence in } \\
\text { animal faeces }\end{array}$ & $\begin{array}{l}\text { Prevalence in } \\
\text { milk }\end{array}$ & References \\
\hline \multirow[t]{8}{*}{ Cattle } & $\begin{array}{l}\text { Central New York } \\
\text { State }\end{array}$ & 50 & Milking cows & 2003-2006 & $43 \%(608 / 1414)$ & $\begin{array}{l}13 \%(184 / \\
1412)\end{array}$ & $\begin{array}{l}\text { Mohammed } \\
\text { et al. (2009) }\end{array}$ \\
\hline & $\begin{array}{l}\text { Central and } \\
\text { southern California }\end{array}$ & 25 & Cow-calf and feedlot operations & 3 times a year & $0.3 \%-3.7 \%$ & nd & $\begin{array}{l}\text { Mohammed } \\
\text { et al. (2010) }\end{array}$ \\
\hline & $\begin{array}{l}\text { Mainly New York } \\
\text { State }\end{array}$ & 52 & Mainly dairy cattle farms & $2001-2003$ & $\begin{array}{l}62.5 \% \\
7.5 \%\end{array}$ & nd & $\begin{array}{l}\text { Nightingale } \\
\text { et al. (2005) }\end{array}$ \\
\hline & Ireland & 4 & $\begin{array}{l}\text { Farms supplying milk to the } \\
\text { unpasteurized milk cheese industry }\end{array}$ & $\begin{array}{l}3 \text { consecutive } \\
\text { months }\end{array}$ & $12 \%(4 / 34)$ & $0 \%$ & Fox et al.,2009 \\
\hline & Italy & 942 & Cow milk & 2019-2013 & nd & $\begin{array}{l}1.7 \%(145 / \\
8716)(2.2 \%\end{array}$ & $\begin{array}{l}\text { Dalzini et al. } \\
\text { (2016) }\end{array}$ \\
\hline & Finland & 3 & Milking cows & 2013-2016 & $23 \%(39 / 169)$ & $13 \%(25 / 186)$ & $\begin{array}{l}\text { Castro et al. } \\
(2018)\end{array}$ \\
\hline & France & 128 & Dairy farms & 1989 & Not studied & $3 \%$ & $\begin{array}{l}\text { Sanaa et al. } \\
(1993)\end{array}$ \\
\hline & Tennessee & 4 & Dairy farms & $2002-2003$ & $1.2 \%(1 / 86)$ & $0 \%(0 / 49)$ & $\begin{array}{l}\text { Murinda et al. } \\
\text { (2004) }\end{array}$ \\
\hline \multirow[t]{2}{*}{$\begin{array}{l}\text { Small } \\
\text { ruminants }\end{array}$} & Austria & 53 & $\begin{array}{l}\text { Ovine and caprine farms with raw milk } \\
\text { processed to cheese and sold directly to } \\
\text { consumers }\end{array}$ & 2009 & $13 \%$ & $0 \%$ & $\begin{array}{l}\text { Schoder et al. } \\
(2011)\end{array}$ \\
\hline & Egypt & $N d$ & Dairy farms sheep and goat & nd & nd & $1.4 \%$ & $\begin{array}{l}\text { Osman et al. } \\
(2014)\end{array}$ \\
\hline Ruminants & Australia & 7 & Dairy farms & 2013-2014 & $6 \%(1 / 16)$ & $0 \%(0 / 15)$ & $\begin{array}{l}\text { MacDade and } \\
\text { Hall, } 1964\end{array}$ \\
\hline
\end{tabular}

Nd: not studied, not applicable or not indicated data.

Table 4

L. monocytogenes detection in udders, bulk tank milk and other milking equipment.

\begin{tabular}{|c|c|c|c|c|c|c|}
\hline \multicolumn{7}{|c|}{ Listeria monocytogenes in milking operations (ruminants) } \\
\hline Type of sample & Animal & Type of production & $\begin{array}{l}\text { Geographical } \\
\text { localization }\end{array}$ & $\begin{array}{l}\text { Number of farms } \\
\text { tested }\end{array}$ & Prevalence & References \\
\hline \multirow[t]{2}{*}{ Udders } & \multirow[t]{6}{*}{ Cattle } & \multirow[t]{5}{*}{ Milking cows } & Central New York State & 50 & $\begin{array}{l}19 \%(268 / \\
1408)\end{array}$ & $\begin{array}{l}\text { Mohammed et al. } \\
\text { (2009) }\end{array}$ \\
\hline & & & Finland & 3 & $17.3 \%(14 / 81)$ & Castro et al. (2018) \\
\hline Udder wipes used & & & & & $13.3 \%(6 / 45)$ & \\
\hline \multirow[t]{5}{*}{ In line milk filters } & & & Central New York State & 50 & $45 \%(62 / 137)$ & $\begin{array}{l}\text { Mohammed et al. } \\
\text { (2009) }\end{array}$ \\
\hline & & & Italy & 27 & $0.5 \%(2 / 378)$ & $\begin{array}{l}\text { Giacometti et al. } \\
\text { (2012) }\end{array}$ \\
\hline & & \multirow[t]{2}{*}{ Dairy farm } & Tennessee & 4 & $4.1 \%(1 / 24)$ & Murinda et al., 2004 \\
\hline & Ruminants & & Australia & 7 & $11 \%(1 / 9)$ & $\begin{array}{l}\text { MacDade and Hall, } \\
1964\end{array}$ \\
\hline & $\begin{array}{l}\text { Small } \\
\text { ruminants }\end{array}$ & $\begin{array}{l}\text { Ovine and caprine milking } \\
\text { farms }\end{array}$ & Austria & 53 & $2.7 \%$ & Schoder et al. (2011) \\
\hline Milk filter tube & Cattle & Milking cows & Finland & 3 & $4.3 \%(4 / 92)$ & Castro et al. (2018) \\
\hline Milk collector & & & & & $0.9 \%(1 / 91)$ & \\
\hline Milk sample cup & & & & & $6.7 \%(2 / 30)$ & \\
\hline \multirow[t]{2}{*}{ Bulk milk samples } & Cattle & & Central New York State & 50 & $16 \%(22 / 137)$ & $\begin{array}{l}\text { Mohammed et al. } \\
\text { (2009) }\end{array}$ \\
\hline & Cattle & & Italy & 942 & $\begin{array}{l}2.2 \%(131 / \\
5897)\end{array}$ & Dalzini et al., 2016 \\
\hline Bulk milk tank outlet & Cattle & & Finland & 3 & $2.7 \%(2 / 74)$ & Castro et al. (2018) \\
\hline Teat cups rack & & & & & $4.1 \%(2 / 48)$ & \\
\hline Stall mats & & & & & $3.3 \%(2 / 61)$ & \\
\hline $\begin{array}{l}\text { Working bench and other } \\
\text { equipment }\end{array}$ & $\begin{array}{l}\text { Small } \\
\text { ruminants }\end{array}$ & $\begin{array}{l}\text { Ovine and caprine milking } \\
\text { farms }\end{array}$ & Austria & 53 & $4.7 \%$ & Schoder et al. (2011) \\
\hline
\end{tabular}

pipeline systems rather than bulk milk systems have been associated with a low risk of $L$. monocytogenes detection (Constable et al., 2016). Specific $L$. monocytogenes strains have been associated with the colonization of milk lines, possibly due to their great ability to form biofilms in this environment for growth (Kostakioti et al., 2013; Latorre et al., 2011), which makes eradication of the bacterium from milk equipment difficult (Oliver et al., 2005). It has also been suggested that contaminated milk in bulk tanks can also act as a source of contamination for the rest of the milking system. (Castro et al., 2018). Therefore, once the bacterium has reached the milk bulk tank, it is recommended to use pre-cooling systems to maintain low bacterial counts (Paludetti et al.,
2018).

Dirty udders have been described as an important source of milk contamination (Castro et al., 2018), with a prevalence of up to $19 \%$ (Mohammed et al., 2019) (Table 4). The bacterium has been reported to be present the surface of uninfected udders or inside the udders, with the latter occurring when there is an infection, such as mastitis. Milk contamination has been associated with incorrect udder hygiene or towel disinfection between milking (Sanaa et al., 1993). Previous studies have shown how incorrect disinfection of udder wipes and towels is associated with contamination of raw milk with L. monocytogenes (Sanaa et al., 1993). Castro et al. (2018) found a contamination prevalence on 
udder surfaces and on udder wipes used after milking of $17.3 \%$ and $13.3 \%$. To avoid contamination at this stage, a strict hygiene protocol must be followed at each milking, with continuous health and hygiene monitoring of animals. In particular, mastitis control routines during each milking are necessary, as well as pre-milking sanitation procedures, which include teat disinfection. The perimammary area of the sheep must be shorn, and bedding must be in good condition to avoid bacterial contamination. Farmers must utilize single-use udder wipes or individual cotton towels that must be disinfected after each milking. Milking should be performed in a hygienic manner, avoiding air inlets and falling teat cups. These practices help not only to reduce microbial contamination before the milking procedure but also to decrease the incidence of udder infections and clinical listeriosis (Hassan et al., 2001; Nightingale et al., 2005).

Milking filters are another important indicator of milk contamination. Poor milking hygiene increases the proportion of debris on the filter surface, which favours the attachment of L. monocytogenes. A milk filter that tested positive for the bacterium is a clear indicator of the presence of the pathogen in the herd and the failure of pre-harvest practices and milking hygiene. It has been suggested that the milk filters are a more sensitive indicator of the bacteria entering the bulk tank than the milk samples alone (Giacometti et al., 2012). Therefore, the screening of filters can be a good method for detecting sanitation problems, not only at the milking level but also in the environment of the herd (Castro et al., 2018). To avoid contamination at this stage of production, correct maintenance is recommended, which includes frequent cleaning, disinfection and changing of these filters to improve the likelihood of detecting bacterial contamination.

Other factors that contribute to the contamination of raw milk at milking are generally poor hygiene, including the hygienic status of the work benches, milk collectors, stall mats, teat cup racks, milk cups and other parts of the milking system that favour bacterial attachment. Good hygiene plans and correct lighting of the facilities during milking operations are necessary to minimize the risk of contamination. It is also recommended that, for good maintenance, the installations should have smooth milk contact surfaces with minimal joints and crevices and that the rubber components should be replaced at regular intervals (Sanaa et al., 1993).

\section{Conclusions}

In this review, we have summarized the different sources of L. monocytogenes contamination described in production farms, and we have analysed the available control measures to reduce bacterial levels and the risk of infection. Feedstuffs are important sources of contamination, and poor-quality silages are primarily responsible for animal carriage and listeriosis outbreaks. Long-term storage and rapid $\mathrm{pH}$ acidification (lower than 4.5) can inhibit the multiplication and survival of the bacterium. Although pastures can be contaminated by faecal shedding of wild and farm animals, the exposure to L. monocytogenes is less than that observed when the animals are housed. Furthermore, access to pasture is an important and beneficial practice not only in terms of listeriosis but also for the physical health, welfare and handling of animals. Regarding wild animals, the access of birds, mice or rats to stocked cereals and grains intended for the herd may cause further contamination. The faeces or carcasses of these animals can contaminate feed, feed bunkers, water and other surfaces on farms. Birds or vermin can cause damage (holes) in silages, leading to marked oxygen penetration and bacterial multiplication. Water and farm soils have also been described as sources of bacterial contamination. Establishing protection zones along surface watercourses, within farms and in buffer zones around farms has been shown to be effective in reducing contamination, as well as maintaining cleanliness of water troughs, pipes, taps and tanks, especially during winter months, when animals are crowded. Proper disinfection of soils is an important practice to reduce the spread of bacteria, especially with the use of enzymatic detergent to detach
L. monocytogenes biofilm cells from surfaces. Correct management and storage of manure and control of foreign agents, with special attention to vehicle wheels, visitor boots and other materials brought into the farm, are necessary to maintain the global hygiene of the farm. Our analysis reveals the impact of bedding materials and quality on L. monocytogenes persistence, transmission and udder contamination. Good quality and assessment of the dryness of the material used for bedding are important measures to minimize contamination. Furthermore, investigation of the different materials for bedding replenishment revealed differences in bacterial counts and altered frequencies. Several studies on manure pathogens have provided a large number of measures to minimize contamination in farms, pastures and crops. It is necessary to avoid the application of fresh animal manure on land, and instead, it is recommended that manure treatment methods, such as pasteurization, anaerobic digestion in biodigesters, chemical disinfection, biogas production and aeration, be introduced. The storage systems of manure must be batch operated, and the storage facilities should be covered to prevent runoff in the environment and block access for wild animals. We also highlight the impact of good hygiene during milking to prevent raw milk contamination, including frequent cleaning and elimination of biofilms from all the equipment. However, in this review analysis, we clearly show that good hygiene practices are not the only important factor in this last part of production, as most of the contamination comes from animal and environmental management. Therefore, all the measures established in the farm and its surroundings at each stage of production will have an important impact on the presence and final counts of $L$. monocytogenes in raw milk.

\section{Funding}

This work was not supported by any external funding.

\section{Ethical statement}

Ethical statement is not applicable.

\section{Data sharing statement}

The data that support the findings of this study are available from the corresponding author upon reasonable request.

\section{Declaration of competing interest}

The authors declare that there is no conflict of interest regarding the publication of this article.

\section{References}

Acciari, V. A., Torresi, M., Iannetti, L., Scattolini, S., Pomilio, F., Decastelli, L., Colmegna, S., Muliari, R., Bossù, T., Proroga, Y., Montagna, C., Cardamone, C., Cogoni, P., Prencipe, V. A., \& Migliorati, G. (2017). Listeria monocytogenes in smoked salmon and other smoked fish at retail in Italy: Frequency of contamination and strain characterization in products from different Manufacturers. Journal of Food Protection, 80(2), 271-278. https://doi.org/10.4315/0362-028X.JFP-15-599.

Addis, M. F., Cubeddu, T., Pilicchi, Y., Rocca, S., \& Piccinini, R. (2019). Chronic intramammary infection by Listeria monocytogenes in a clinically healthy goat - a case report. BMC Veterinary Research, 15(1), 229. https://doi.org/10.1186/s12917-0191989-3.

Aksono, E. B., Riwu, K. H. P., Estoepangestie, A. T. S., \& Pertiwi, H. (2020). Phylogenetic analysis and antibiotics resistance of Listeria monocytogenes contaminating chicken meat in surabaya, Indonesia. Veterinary Medicine International Medicine, 1, Article 9761812. https://doi.org/10.1155/2020/9761812.

Amado, I. R., Fuciños, C., Fajardo, P., \& Pastrana, L. (2016). Pediocin SA-1: A selective bacteriocin for controlling Listeria monocytogenes in maize silages. Journal of Dairy Science, 99(10), 8070-8080. https://doi.org/10.3168/jds.2016-11121.

Arnott, G., Ferris, C. P., \& O'Connell, N. E. (2017). Review: Welfare of dairy cows in continuously housed and pasture-based production systems. Animal, 11(2), 261-273. https://doi.org/10.1017/S1751731116001336.

Bale, M. J., Bennett, P. M., Beringer, J. E., \& Hinton, M. (1993). Effect of relative humidity on surface-exposed organisms. American Journal of Hygiene, 80, 192-204. 
Biswas, S., Niu, M., Pandey, P., Appuhamy, J. A. D. R. N., Leytem, A. B., Kebreab, E., \& Dungan, R. S. (2018). Effect of dairy manure storage conditions on the survival of E. coli O157:H7 and Listeria. Journal of Environmental Quality, 47(1), 185-189. https:// doi.org/10.2134/jeq2017.06.0224. doi:10.2134/jeq2017.06.0224.

Bonetta, S., Ferretti, E., Bonetta, S., Fezia, G., \& Carraro, E. (2011). Microbiological contamination of digested products from anaerobic co-digestion of bovine manure and agricultural by-products. Letters in Applied Microbiology, 53(5), 552-557. https:// doi.org/10.1111/j.1472-765X.2011.03148.x.

Borucki, M. K., \& Douglas, R. (2003). Listeria monocytogenes serotype identification by PCR. Journal of Clinical Microbiology, 41(12), 5537-5540. https://doi.org/10.1128/ JCM.41.12.5537-5540.2003.

Bourry, A., Poutrel, B., \& Rocourt, J. (1995). Bovine mastitis caused by Listeria monocytogenes: Characteristics of natural and experi-mental infections. Journal of Medicine Microbiology, 43, 125-132. https://doi.org/10.1099/00222615-43-2-125.

Bradley, A. J., Leach, K. A., Green, M. J., Gibbons, J., Ohnstad, I. C., Black, D. H., Payne, B., Prout, V. E., \& Breen, J. E. (2018). The impact of dairy cows' bedding material and its microbial content on the quality and safety of milk - a cross sectional study of UK farms. International Journal of Food Microbiology, 23(269), 36-45. https://doi.org/10.1016/j.ijfoodmicro.2017.12.022.

Castro, H., Jaakkonen, A., Hakkinen, M., Korkeala, H., \& Lindström, M. (2018). Occurrence, persistence, and contamination routes of Listeria monocytogenes genotypes on three Finnish dairy cattle farms: A Longitudinal study. Applied and Environmental Microbiology, 84, 4. https://doi.org/10.1128/AEM.02000-17.

Coblentz, W. K., \& Akins, M. S. (2018). Silage review recent advances and future technologies for baled silages. Journal of Dairy Science, 101(5), 4075-4092. https:// doi.org/10.3168/jds.2017-13708.

Constable, P., Hinchcliff, K. W., Done, S., \& Gruenberg, W. (2016). Veterinary Medicine 11th A textbook of diseases of cattle, horses, sheep, pigs and goats (p. 2278). Saunders LTD. Elsevier. Hardcover ISBN:9780702052460,

Dalzini, E., Bernini, V., Bertasi, B., Daminelli, P., Losio, M. N., \& Varisco, G. (2016). Survey of prevalence and seasonal variability of Listeria monocytogenes in raw cow milk from Northern Italy. Food Control, 60, 466-470. https://doi.org/10.1016/j. foodcont.2015.08.019.

Dell'Armelina-Rocha, P. R., Lomonaco, S., Bottero, M. T., Dalmasso, A., Dondo, A., Grattarola, C., Zuccon, F., Iulini, B., Knabel, S. J., Capucchio, M. T., \& Casalone, C. (2013). Ruminant rhombencephalitis-associated Listeria monocytogenes strains constitute a genetically homogeneous group related to human outbreak strains. Applied and Environmental Microbiology, 79(9), 3059-3066. https://doi.org/10.1128/ AEM.00219-13.

Dhama, K., Verma, A. K., Rajagunalan, S., Kumar, A., Tiwari, R., Chakraborty, S., \& Kumar, R. (2013). Listeria monocytogenes infection in poultry and its public health importance with special reference to food borne zoonoses. Pakistan Journal of Biological Sciences, 16(7), 301-308. https://doi.org/10.3923/pjbs.2013.301.308.

Dreyer, M., Thomann, A., Böttcher, S., Frey, J., \& Oevermann, A. (2015). Outbreak investigation identifies a single Listeria monocytogenes strain in sheep with different clinical manifestations, soil and water. Veterinary Microbiology, 179(1-2), 69-75. https://doi.org/10.1016/j.vetmic.2015.01.025.

Driehuis, F., \& Elferink, S. O. (2000). The impact of the quality of silage on animal health and food safety: A review. Veterinary Quartely, 22(4), 212-216. https://doi.org/ 10.1080/01652176.2000.9695061.

FAO. (2020). http://www.fao.org/land-water/news/news-details/es/c/1032702/.

Fenlon, D. R. (1986). Growth of naturally occurring Listeria spp. in silage: A comparative study of laboratory and farm ensiled grass. Grass and Forage Science, 41(4), 375-378. https://doi.org/10.1111/j.1365-2494.1986.tb01828.x.

Fox, E., Hunt, K., O'Brien, M., \& Jordan, K. (2011). Listeria monocytogenes in Irish Farmhouse cheese processing environments. International Journal of Food Microbiology, 145(Suppl 1), S39-S45. https://doi.org/10.1016/j. ijfoodmicro.2010.10.012.

Giacometti, F., Serraino, A., Finazzi, G., Daminelli, P., Losio, M. N., Bonilauri, P., Arrigoni, N., Garigliani, A., Mattioli, R., Alonso, S., Piva, S., Florio, D., Riu, R., \& Zanoni, R. G. (2012). Foodborne pathogens in in-line milk filters and associated onfarm risk factors in dairy farms authorized to produce and sell raw milk in northern Italy. Journal of Food Protection, 75(7), 1263-1269. https://doi.org/10.4315/0362028X.

Gronstol, H. (1979). Listeriosis in sheep. Isolation of Listeria monocytogenes from grass silage. Acta Veterinaria Scandinava, 20(4), 492-497.

Hassan, L., Mohammed, H. O., \& McDonough, P. L. (2001). Farm-management and milking practices associated with the presence of Listeria monocytogenes in New York state dairy herds. Preventive Veterinary Medicine, 51(1-2), 63-73.

Heinonen-Tanski, H., Mohaibes, M., Karinen, P., \& Koivunen, J. (2006). Methods to reduce pathogen microorganisms in manure. Livestock Science, 102(3), 248-255. https://doi.org/10.1016/j.livsci.2006.03.024.

Hellström, S., Laukkanen, R., Siekkinen, K. M., Ranta, J., Maijala, R., \& Korkeala, H. (2010). Listeria monocytogenes contamination in pork can originate from farms. Journal of Food Protection, 73(4), 641-648. https://doi.org/10.4315/0362-028x73.4.641.

Himathongkham, S., \& Riemann, H. (1999). Destruction of Salmonella typhimurium, Escherichia coli 0157:H7 and Listeria monocytogenes in chicken manure by drying and/or gassing with ammonia. FEMS Microbiology Letters, 171(2), 179-182. https:// doi.org/10.1111/j.1574-6968.1999.tb13430.x.

Ho, A. J., Ivanek, R., Gröhn, Y. T., Nightingale, K. K., \& Wiedmann, M. (2007). Listeria monocytogenes fecal shedding in dairy cattle shows high levels of day-to-day variation and includes outbreaks and sporadic cases of shedding of specific L. monocytogenes subtypes. Preventive Veterinary Medicine, 80(4), 287-305. https:// doi.org/10.1016/j.prevetmed.2007.03.005.
Husfeldt, A. W., Endres, M. I., Salfer, J. A., \& Janni, K. A. (2012). Management and characteristics of recycled manure solids used for bedding in Midwest freestall dairy herds. Journal of Dairy Science, 95(4), 2195-2203. https://doi.org/10.3168/ jds.2011-5105.

Husu, J. R. (1990). Epidemiological studies on the occurrence of Listeria monocytogenes in the feces of dairy cattle. Journal of Veterinary Medicine Series B, 37, 276. https://doi. org/10.1111/j.1439-0450.1990.tb01059.x.

Hutchison, M. L., Walters, L. D., Avery, S. M., \& Moore, A. (2005). Decline of zoonotic agents in livestock waste and bedding heaps. Journal of Applied Microbiology, 99(2), 354-362. https://doi.org/10.1111/j.1365-2672.2005.02591.x.

Ivanek, R., Grohn, Y. T., Wells, M. T., Lembo, A. J., Sauders, B. D., \& Wiedmann, M. (2009). Modelling of spatially referenced environmental and meteorological factors influencing the probability of Listeria species isolation from natural environments. Applied and Environmental Microbiology, 75, 5893-5909. https://doi.org/10.1128/ AEM.02757-08.

Kim, J., \& Jiang, X. (2010). The growth potential of Escherichia coli 0157:H7, Salmonella spp. and Listeria monocytogenes in dairy manure-based compost in a greenhouse setting under different seasons. Journal of Applied Microbiology, 109, 2095-2104.

Konosonoka, I. H., Jemeljanovs, A., Osmane, B., Ikauniece, D., \& Gulbe, G. (2012). Incidence of Listeria spp. in dairy cows feed and raw milk in Latvia. ISRN Veterinary Science, 26, Article 435187. https://doi.org/10.5402/2012/435187.

Koopmans, M. M., Bijlsma, M. W., Brouwer, M. C., van de Beek, D., \& van der Ende, A. (2017). Listeria monocytogenes meningitis in The Netherlands, 1985-2014: A nationwide surveillance study. Journal of Infection, 5(1), 12-19. https://doi.org/ 10.1016/j.jinf.2017.04.004.

Ko, R., Smith, L. T., \& Smith, E. M. (1994). Glycine betaine confers enhanced osmotolerance and cryotolerance on Listeria monocytogenes. Journal of Bacterology, 176, 426-431.

Kostakioti, M., Hadjifrangiskou, M., \& Hultgren, S. J. (2013). Bacterial biofilms: Development, dispersal, and therapeutic strategies in the dawn of the postantibiotic era. Cold Spring Harbor Perspectives in Biology, 3(4), Article a010306. https://doi.org/ 10.1101/cshperspect.a010306.

Lakicevic, B., Nastasijevica, I., \& Rasetaa, M. (2015). Sources of Listeria monocytogenes contamination in retail establishments. Procedia Food Science, 5, 160-163. https:// doi.org/10.1016/j.profoo.2015.09.046.

Latorre, A. A., Van Kessel, J. A., Karns, J. S., Zurakowski, M. J., Pradhan, A. K., Boor, K. J., Adolph, E., Sukhnanand, S., \& Schukken, Y. H. (2011). Increased in vitro adherence and on-farm persistence of predominant and persistent Listeria monocytogenes strains in the milking system. Applied and Environmental Microbiology, 77(11), 3676-3684. https://doi.org/10.1128/AEM.02441-10.

Latorre, A. A., Van Kessel, J. S., Karns, J. S., Zurakowski, M. J., Pradhan, A. K., Boor, K. J., Jayarao, B. M., Houser, B. A., Daugherty, C. S., \& Schukken, Y. H. (2010). Biofilm in milking equipment on a dairy farm as a potential source of bulk tank milk contamination with Listeria monocytogenes. Journal of Dairy Science, 93(6), 2792-2802. https://doi.org/10.3168/jds.2009-2717.

Limin Kung, J. R., Shaver, R. D., Grant, R. J., \& Schmidt, R. J. (2018). Silage review: Interpretation of chemical, microbial, and organoleptic components of silage. Journal of Dairy Science, 101, 4020-4033. https://doi.org/10.3168/jds.2017-13909.

Linke, K., Rückerl, I., Brugger, K., Karpiskova, R., Walland, J., Muri-Klinger, S., Tichy, A., Wagner, M., \& Stessl, B. (2014). Reservoirs of Listeria species in three environmental ecosystems. Applied and Environmental Microbiology, 80(18), 5583-5592. https://doi. org/10.1128/AEM.01018-14.

Locatelli, A., Depret, G., Jolivet, C., Henry, S., Dequiedt, S., Piveteau, P., \& Hartmann, A. (2013). Nation-wide study of the occurrence of Listeria monocytogenes in French soils using culture-based and molecular detection methods. Journal of Microbiological Methods, 93(3), 242-250. https://doi.org/10.1016/j.mimet.2013.03.017.

LPSN. (2020) Accessed Mars 2020 https://lpsn.dsmz.de/genus/listeria.

MacDade, J. J., \& Hall, L. B. (1964). Survival of Gram-negative bacteria in the environment. I. Effect of relative humidity on surface-exposed organisms. American Journal of hygene, 80, 192-204.

Mantovani, H. C., \& Russell, J. B. (2003). Inhibition of Listeria monocytogenes by bovicin HC5, a bacteriocin produced by Streptococcus bovis HC5. International Journal of Food Microbiology, 89(1), 77-83. https://doi.org/10.1016/s0168-1605(03)00110-7.

Manyi-Loh, C. E., Mamphweli, S. N., Meyer, E. L., Makaka, G., Simon, M., \& Okoh, A. I. (2016). An overview of the control of bacterial pathogens in cattle manure. International Journal of Environmental Research and Public Health, 13(9), 843. https:// doi.org/10.3390/ijerph13090843.

Matto, C., Varela, G., Mota, M. I., Gianneechini, R., \& Rivero, R. (2017). Rhombencephalitis caused by Listeria monocytogenes in a pastured bull. Journal of Veterinary Diagnostic Investigation, 29(2), 228-231. https://doi.org/10.1177/ 1040638716689116.

McDonald, P., Henderson, A. R., \& Heron, S. J. E. (1991). The biochemistry of silage ( $2^{\text {nd }}$ ed.). Marlow, Buckinghamshire UK: Chalcombe Publications.

Mee, J. F., \& Boyle, L. A. (2020). Assessing whether dairy cow welfare is "better" in pasture-based than in confinement-based management systems. New Zealand Veterinary Journal, 68(3), 168-177. https://doi.org/10.1080/ 00480169.2020.1721034.

Mohammed, H. O., Atwill, E., Dunbar, L., Ward, T., McDonough, P., Gonzalez, R., \& Stipetic, K. (2010). The risk of Listeria monocytogenes infection in beef cattle operations. Journal of Applied Microbiology, 108(1), 349-356. https://doi.org/ 10.1111/j.1365-2672.2009.04446.x.

Mohammed, H. O., Stipetic, K., McDonough, P. L., Gonzalez, R. N., Nydam, D. V., \& Atwill, E. R. (2009). Identification of potential on-farm sources of Listeria monocytogenes in herds of dairy cattle. American Journal of Veterinary Research, 70(3), 383-388. https://doi.org/10.2460/ajvr.70.3.383. 
Moshtaghi, H., Garg, S. R., \& Mandokhot, U. V. (2003). Prevalence of Listeria in soil. Indian Journal of Experimental Biology, 41(12), 1466-1468.

Murinda, S. E., Nguyen, L. T., Nam, H. M., Almeida, R. A., Headrick, S. J., \& Oliver, S. P. (2004). Detection of sorbitol-negative and sorbitol-positive Shiga toxin-producing Escherichia coli, Listeria monocytogenes, Campylobacter jejuni, and Salmonella spp. in dairy farm environmental samples. Foodborne Pathogens and Diseases, 1(2), 97-104. https://doi.org/10.1089/153531404323143611.

Nightingale, K. K., Fortes, E. D., Ho, A. J., Schukken, Y. H., Grohn, Y. T., \& Wiedmann, M. (2005). Evaluation of farm management practices as risk factors for clinical listeriosis and fecal shedding of Listeria monocytogenes in ruminants. Journal of the American Veterinary Medical Association, 227(11), 1808-1814.

Nightingale, K. K., Schukken, Y. H., Nightingale, C. R., Fortes, E. D., Ho, A. J., Her, Z., Grohn, Y. T., McDonough, P. L., \& Wiedmann, M. (2004). Ecology and transmission of Listeria monocytogenes infecting ruminants and in the farm environment. Applied and Environmental Microbiology, 70(8), 4458-4467. https://doi.org/10.1128/ AEM.70.8.4458-4467.2004.

Nucera, D. M., Grassi, M. A., Morra, P., Piano, S., Tabacco, E., \& Borreani, G. (2016). Detection, identification and typing of Listeria species from baled silages fed to dairy cows. Journal of Dairy Science, 99, 6121-6133. https://doi.org/10.3168/jds.201610928.

Oevermann, A., Zurbriggen, A., \& Vandevelde, M. (2010). Rhombencephalitis caused by Listeria monocytogenes in humans and ruminants: A Zoonosis on the Rise? Interdisciplinary Perspectives on Infectious Diseases, 2010, Article 632513. https://doi. org/10.1155/2010/632513.

Oh, H., Kim, S., Lee, S., Lee, H., Ha, J., Lee, J., Choi, Y., Choi, K. H., \& Yoon, Y. (2016). Prevalence and genetic characteristics of meatborne Listeria monocytogenes isolates from livestock farms in Korea. Korean Journal for Food Science of Animal Resources, 36 (6), 779-786. https://doi.org/10.5851/kosfa.2016.36.6.779.

Oliver, S. P., Jayarao, B. M., \& Almeida, R. A. (2005). Foodborne pathogens in milk and the dairy farm environment: Food safety and public health implications. Foodborne Pathogens and Diseases, 2, 115-129. https://doi.org/10.1089/fpd.2005.2.115.

Osman, K. M., Zolnikov, T. R., Samir, A., \& Orabi, A. (2014). Prevalence, pathogenic capability, virulence genes, biofilm formation, and antibiotic resistance of Listeria in goat and sheep milk confirms need of hygienic milking conditions. Pathogens and Global Health, 108(1), 21-29. https://doi.org/10.1179/2047773213Y.0000000115.

Pang, H., McEgan, R., Mishra, A., Micallef, S. A., \& Pradhan, A. K. (2017). Identifying and modelling meteorological risk factors associated with pre-harvest contamination of Listeria species in mixed produced and dairy farm. Food Research International, 102, 355-363. https://doi.org/10.1016/j.foodres.2017.09.029.

Pang, M., Xie, X., Bao, H., Sun, L., He, T., Zhao, H., Zhou, Y., Zhang, L., Zhang, H., Wei, R., Xie, K., \& Wang, R. (2018). Insights into the bovine milk microbiota in dairy farms with different incidence rates of subclinical mastitis. Frontiers in Microbiology, 16(9), 2379. https://doi.org/10.3389/fmicb.2018.02379.

Papić, B., Golob, M., Kušar, D., Pate, M., \& Zdovc, I. (2019). Source tracking on a dairy farm reveals a high occurrence of subclinical mastitis due to hypervirulent Listeria monocytogenes clonal complexes. Journal of Applied Microbiology, 127(5), 1349-1361. https://doi.org/10.1111/jam.14418.

Pauly, T. M., \& Tham, W. A. (2003). Survival of Listeria monocytogenes in wilted and additive-treated grass silage. Acta Veterinaria Scandinavica, 44(1-2), 73-86. https:// doi.org/10.1186/1751-0147-44-73.

Rasmussen, O. F., Skouboe, P., Dons, L., Rossen, L., \& Olsen, J. E. (1995). Listeria monocytogenes exists in at least three evolutionary lines: Evidence from flagellin, invasive associated protein and listeriolysin O genes. Microbiology, 141(Pt 9), 2053-2061.

Ripolles-Avila, C., Ramos-Rubio, M., Hascoët, A. S., Castillo, M., \& Rodríguez-Jerez, J. J. (2020). New approach for the removal of mature biofilms formed by wild strains of Listeria monocytogenes isolated from food contact surfaces in an Iberian pig processing plant. International Journal of Food Microbiology, 19, 323. https://doi.org/ 10.1016/j.ijfoodmicro.2020.108595, 108595.

Roberts, B. N., Bailey, R. H., McLaughlin, M. R., \& Brooks, J. P. (2016). Decay rates of zoonotic pathogens and viral surrogates in soils amended with biosolids and manures and comparison of qPCR and culture derived rates. The Science of the Total Environment, 15(573), 671-679. https://doi.org/10.1016/j.scitotenv.2016.08.088.

Roberts, B. N., Chakravarty, D., Gardner, J. C., III., Ricker, S. C., \& Donaldson, J. R. (2020). Listeria monocytogenes response to anaerobic environments. Pathogens, 9(3), 210. https://doi.org/10.3390/pathogens9030210.

Rothrock, M. J., Jr., Davis, M. L., Locatelli, A., Bodie, A., McIntosh, T. G., Donaldson, J. R., \& Ricke, S. C. (2017). Listeria occurrence in poultry flocks: Detection and potential implications. Frontiers in Veterinary Science, 4, 125. https:// doi.org/10.3389/fvets.2017.00125.

Ruxton, G. D., \& Gibson, G. J. (1995). A mathematical model of anaerobic deterioration of big-sale silage and its implication for the growth of Listeria monocytogenes. Grass and Forage Science, 1, 331-344.

Sanaa, M., Poutrel, B., Menard, J. L., \& Serieys, F. (1993). Risk factors associated with contamination of raw milk by Listeria monocytogenes in dairy farms. Journal of Dairy Science, 76(10), 2891-2898. https://doi.org/10.3168/jds.S0022-0302(93)77628-6.

Santos, M. C., Lock, A. L., Mechor, G. D., \& Kung, L. J. (2015). Effects of spoilage yeast from silage on in vitro ruminal fermentation. Journal of Diary Science, 98(4), 2603-2610. https://doi.org/10.3168/jds.2014-8683.
Scheinemann, H. A., Dittmar, K., Stöckel, F. S., Müller, H., \& Krüger, M. E. (2015). Hygienisation and nutrient conservation of sewage sludge or cattle manure by lactic acid fermentation, 10 PLoS One, 18(3). https://doi.org/10.1371/journal. pone.0118230. e0118230.

Schoder, D., Melzner, D., Schmalwieser, A., Zangana, A., Winter, P., \& Wagner, M. (2011). Important vectors for Listeria monocytogenes transmission at farm dairies manufacturing fresh sheep and goat cheese from raw milk. Journal of Food Protection, 74(6), 919-924. https://doi.org/10.4315/0362-028X.JFP-10-534.

Sewell, D., Allen, S. C., \& Phillips, C. A. (2015). Oxygen limitation induces acid tolerance and impacts simulated gastrointestinal transit in Listeria monocytogenes J0161. Gut Pathogens, 7, 11.

Shamloo, E., Hosseini, H., Abdi-Moghadam, Z., Halberg-Larsen, M., Haslberger, A., \& Alebouyeh, M. (2019). Importance of Listeria monocytogenes in food safety: A review of its prevalence, detection, and antibiotic resistance. Iranian Journal of Veterinary Research, 20(4), 241-254.

Smith, A., Moorhouse, E., Monaghan, J., Taylor, C., \& Singleton, I. (2018). Sources and survival of Listeria monocytogenes on fresh, leafy produce. Journal of Applied Microbiology, 125(4), 930-942. https://doi.org/10.1111/jam.14025.

Stein, H., Stessl, B., Brunthaler, R., Loncaric, I., Weissenböck, H., Ruczizka, U., Ladinig, A., \& Schwarz, L. (2018). Listeriosis in fattening pigs caused by poor quality silage - a case report. BMC Veterinary Research, 21(1), 362. https://doi.org/10.1186/ s12917-018-1687-6, 14.

Strawn, L., Fortes, E., Bihn, E., Nightingale, K., Grohn, Y., Worobo, R., Wiedmann, M., \& Bergholz, P. (2013). Landscape and meteorological factors affecting prevalence of three foodborne pathogens in fruit and vegetable farms. Applied and Environmental Microbiology, 79, 588-600. https://doi.org/10.1128/AEM.02491-12.

Takai, S., Orii, F., Yasuda, K., Inoue, S., \& Tsubaki, S. (1990). Isolation of Listeria monocytogenes from raw milk and its environment at dairy farms in Japan. Microbiology and Immunology, 34(7), 631-634. https://doi.org/10.1111/j.13480421.1990.tb01038.x.

Tamang, R. K., Jha, G. J., Chauhan, H. V. S., \& Tiwari, B. K. (1988). In vivo immunosuppression by synthetic pyrethroid (Cypermethrin) pesticide in mice and goat. Veterinary Immunology and ImmunoPathology, 19, 299-305.

Tzora, A., Fthenakis, G. C., \& Linde, K. (1998). The effects of inoculation of Listeria monocytogenes into the ovine mammary gland. Veterinary Microbiology, 59(2-3), 193-202. https://doi.org/10.1016/s0378-1135(97)00195-8, 1998.

Welshimer, H. J. (1968). Isolation of Listeria monocytogenes from vegetation. Journal of Bacteriology, 95(2), 300-303.

Welshimer, H. J., \& Donker-Voet, J. (1971). Listeria monocytogenes in nature. Applied Microbiology, 21(3), 516-519.

White, S. L., Benson, G. A., Washburn, S. P., \& Green, J. T. J. (2002). Milk production and economic measures in confinement or pasture systems using seasonally calved Holstein and Jersey cows. Journal of Dairy Science, 85(1), 95-104. https://doi.org/ 10.3168/jds.S0022-0302(02)74057-5.

Whitman, K. J., Bono, J. L., Clawson, M. L., Loy, J. D., Bosilevac, J. M., Arthur, T. M., \& Ondrak, J. D. (2020). Genomic-based identification of environmental and clinical Listeria monocytogenes strains associated with an abortion outbreak in beef heifers. BMC Veterinary Research, 16, 70. https://doi.org/10.1186/s12917-020-2276-z.

Wiedmann, M., Bruce, J. L., Keating, C., Johnson, A. E., McDonough, P. L., \& Batt, C. A. (1997). Ribotypes and virulence gene polymorphisms suggest three distinct Listeria monocytogenes lineages with differences in pathogenic potential. Infection and Inmunity, 65(7), 2707-2716.

Wiedmann, M., Czajka, J., Bsat, N., Bodis, M., Smith, M. C., Divers, T. J., \& Batt, C. A. (1994). Diagnosis and epidemiological association of Listeria monocytogenes strains in two outbreaks of listerial encephalitis in small ruminants. Journal of Clinical Microbiology, 32(4), 991-996.

Winter, P., Schilcher, F., Bagò, Z., Schoder, D., Egerbacher, M., Baumgartner, W., \& Wagner, M. (2004). Clinical and histopathological aspects of naturally occurring mastitis caused by Listeria monocytogenes in cattle and ewes. Journal of Veterinary Mededicine. B, Infectious Disease and Veterinary Public Health, 51(4), 176-179. https:// doi.org/10.1111/j.1439-0450.2004.00751.x.

Zhu, K., Ding, X., Julotok, M., \& Wilkinson, B. J. (2005). Exogenous isoleucine and fatty acid shortening ensure the high content of antesio-C15:0 fatty acid required for lowtemperature growth of Listeria monocytogenes. Applied and Environmental Microbiology, 71(12), 8002-8007. https://doi.org/10.1128/AEM.71.12.80028007.2005.

Zoz, F., Grandvalet, C., Lang, E., Iaconelli, C., Gervais, P., Firmesse, O., Guyot, S., \& Beney, L. (2017). Listeria monocytogenes ability to survive desiccation: Influence of serotype, origin, virulence, and genotype. International Journal of Food Microbiology, 248, 82-89. https://doi.org/10.1016/j.ijfoodmicro.2017.02.010.

\section{Further reading}

Driehuis, F., Wilkinson, J. M., Jiang, Y., Ogunade, I., \& Adesogan, A. T. (2008). Silage review: Animal and human health risks from silages. Journal of diary science, 101(5), 4093-4110. https://doi.org/10.3168/jds.2017-13836.

Roberts, A. J., \& Wiedmann, M. (2003). Pathogen, host and environmental factors contributing to the pathogenesis of listeriosis. Cellular and Molecular Life Sciences, 60, 1-15. https://doi.org/10.1007/s00018-003-2225-6. 